Chapter 13

\title{
Mismatch in Teachers' Ontological Conception of Entrepreneurship Education
}

\author{
Kaarlo Paloniemi and Pekka Belt \\ Additional information is available at the end of the chapter \\ http://dx.doi.org/10.5772/59272
}

\section{Introduction}

According to literature, entrepreneurship education (EE) teachers face difficulties in their everyday work when they attempt to combine the content of entrepreneurship and the educational methods required to teach it [1-4]. To understand this phenomenon more thoroughly, Fayolle [5] raises a question relating to the basic elements of EE: "What are we talking about when we talk about entrepreneurship education?" To overcome the conceptual confusion, researchers in the field call for theoretical and conceptual studies focusing on ontological and epistemological issues.

In entrepreneurship, there are two ontologically different theories describing its core: opportunity discovery and opportunity creation. These two theories share some key aspects; however, their ontological bases are very different. While discovery theorists see opportunities as existing independently of entrepreneurs, for creation theorists opportunities are created by entrepreneurs [6]. Moreover, discovery theorists see entrepreneurship as systematic cognitive calculation where the level of risk can be calculated and future predicted once enough information has been collected. According to this view, the reality is the same for everybody and, consequently, any intelligent entrepreneur will get the same calculation result and will be able to evaluate the feasibility of any existing opportunity. In other words, the ontological view of discovery theory is based on realism; that is, opportunities exist independently of perceptions of them [6]. However, for the creation theorists, the context is uncertain or ambiguous (i.e., entrepreneurs are unable to predict the future) [7]. The future needs to be created by human actions. Therefore, the ontological view of creation theory is based on idealism, meaning that opportunities are creations of human beings [6].

In education, behavioristic learning conception bases itself on ontological assumptions originating from realism in the same manner as discovery theory in entrepreneurship. The 
knowledge to be taught is viewed to exist already and the knowledge is considered as a fact that is similar for everybody [8]. Moreover, the teacher is capable of systematically transferring this knowledge unchanged according to objectives set beforehand. Conversely, social constructionist learning conception bases itself, in line with creation theory, on idealism; knowledge is not ready to be picked up; rather, learners construct new knowledge in cooperation with peer students, using the knowledge and know-how of these colleagues as well as the support of their teachers $[9,10]$.

The ontological bases of behaviorism and social constructionism learning theories are fundamentally different. Behaviorists, because of their roots in realism [11, 12], believe that reality exists independently of perceptions of it. Social constructionists believe that no independent reality exists, or that reality may exist but cannot be known ex ante. Thus, they base their theoretical thinking on idealism (i.e., only our constructions of reality exist) [13,14]. Therefore, we believe that both behaviorists and opportunity discoverers focus on external observations of observable issues (stimuli) and the reactions that follow. Thus, they reject the idea that knowledge depends on an individual's mental state. That is, "there is no subjective element to learning-either in determining what to study or how information is interpreted, used, or understood" [15]. Social constructivists and opportunity creators believe that human beings are able to construct their own knowledge by interpreting multiple perspectives of the world, rather than by replicating only one true perspective, as viewed by realists. Thus, realism and idealism represent two polarized perspectives on reality; objective reality at one end and subjective reality consisting of multiple realities on the other. If EE teachers adopt a realist position, then, at the same time, they reject the possibility that their students will construct their own interpretations of the findings. That is, they just assume that what is reported as opportunity actually is a true opportunity. If EE teachers follow idealism, it leads them to conclude that it is students who create opportunities through exploration, collaboration, or co-creation. The opportunities they create can never be known as "true" opportunities ex ante. That is because there is no single reality, but multiple realities, none of which has precedence over the other in terms of claims to represent the truth about social phenomena [15].

The aim of this chapter is to study, from an ontological point of view, the recent theoretical developments in both entrepreneurship and education, and to discuss the impact of possible ontological discrepancies in teachers' conceptions of entrepreneurship education. That is, we base our approach on the insight that, first, the modern entrepreneurship literature favors opportunity creation over opportunity discovery and that, simultaneously, the modern literature on education prefers the views of social constructionism to behaviorism. Second, we see that while teachers of entrepreneurship education at any level of our education system are able to match these recent theoretical standpoints, they still seem to base the entrepreneurial part of entrepreneurship education on traditional theories, rather than on the modern view of entrepreneurship. Finally, we see that teachers at the university level seem to cling to ontological conceptions of traditional theories of both entrepreneurship and education. Thus, there seems to be a mismatch in entrepreneurship teachers' ontological conception between entrepreneurship and the educational methods teachers are using to organize their activities for entrepreneurship education. 
In order to ease EE teachers' ontological headaches in understanding entrepreneurship and education, we will first focus on literature to find out whether or not there is a mismatch between EE teachers' conceptions of entrepreneurship and education. Second, we will focus on opportunity creation from the middle-ground perspective of critical realism to ease some of the ontological controversy in EE teachers' conceptions of entrepreneurship and education.

\section{Method}

In this conceptual study, our focus is on EE teachers' conceptions of entrepreneurship and education. The aim of the study is to clarify the ontological factors that explain the confusion EE teachers face in conceiving entrepreneurship and the methods used to teach it. In addition, we aim to depict a coherent model of ontological aspects that explicitly looks at both theoretical entities of EE: entrepreneurship and education as EE teachers' conceptions of EE can be expected to be influenced by their conceptions of entrepreneurship and education. Because there is no shared understanding to conceptualize EE, we aim to describe EE as an integration of two domains: entrepreneurship and education.

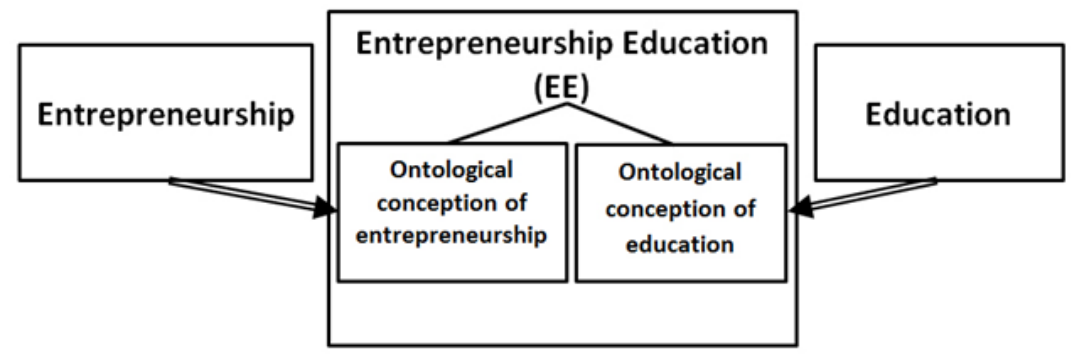

Figure 1. The components of EE teachers' ontological conception of EE when EE is viewed as an integration of entrepreneurship and education.

To analyze a potential ontological mismatch in EE teachers' conceptions between entrepreneurship and education, we first review scientific journal articles, project reports, and official European and national documents discussing EE. We then compare our findings with the feedback we have received from EE teachers at primary, secondary, and tertiary educational levels, as well as with our own personal experiences. We also juxtapose the ontological perspectives of entrepreneurship and education. Combining conceptual reasoning and empirical observations enables fruitful interplay between theory and practice. Therefore, our methodological approach follows the reflective practice described in [16, 17]. 


\section{Literature review and analysis}

\subsection{Entrepreneurship}

There are two entrepreneurship theories for EE teachers to choose from: opportunity discovery and opportunity creation. According to the scientific literature, these two theories share some key aspects; nevertheless, they are very different. Even though both of these theories seek to explain entrepreneurial actions and their impact on the entrepreneur's ability to form and exploit opportunities, their ontological conceptions of opportunity, entrepreneur, and entrepreneurial decision-making differ [6]. Discovery theorists see opportunities as existing independently of entrepreneurs, and opportunities are formed by shocks in industries or markets $[6,18]$. According to creation theorists, entrepreneurs create opportunities. Discovery theorists believe that entrepreneurs, as persons, differ - ex ante from non-entrepreneurs. Creation theorists agree that there may be differences; nevertheless, those differences may be experienced only ex post. Also, the contexts where entrepreneurs make their decisions are viewed differently by discovery and creation theorists. While discoverists view the context as risky (i.e., entrepreneurs may calculate the risk level by collecting adequate amounts of information), creation theorists see the context as uncertain or ambiguous (i.e., entrepreneurs cannot predict the future).

Recent entrepreneurship literature favors a paradigm shift from causation to effectuation that better suits entrepreneurship in uncertain business environments [7, 19]. Causation follows the traditional decision-making process, requiring the entrepreneur to collect information for goal-setting and planning. As a consequence, the entrepreneur is able to predict future actions and events [19, 20, 21]. Thus, causation is based on the assumption that a business opportunity is first discovered, after which business functions are systematically established. Therefore, causation prefers EE that promotes understanding of business functions and business planning. We can conclude that there are obvious ontological parallels between opportunity discovery theory and causation.

In a turbulent business environment, successful entrepreneurs typically use effectuation [19, 20, 21]. Effectual entrepreneurs start by thinking of who they are, what they know and whom they know [7]. Instead of first setting goals, effectual entrepreneurs start with given resources and let goals develop over time from the imagination and actions of involved people. Thus, effectuation is based on the awareness of available resources, including the entrepreneur's personal competences and those of stakeholders $[19,20]$. We conclude that effectuation is based on the assumption that entrepreneurs create business opportunities in interaction with other stakeholders and with the environment. From the ontological perspective, effectuation and opportunity creation can thus be assimilated. In addition, the ontological perception of effectuation can be considered to match with the ontological perception of social constructionism. 


\subsection{Entrepreneurship education}

Entrepreneurship has traditionally been viewed as needing managerial competences and knowledge about business functions. More recent scientific entrepreneurship literature, however, highlights innovative, entrepreneurial competences in turbulent operational environments. The same viewpoints can be traced in EE; while traditional EE aims to develop students' competences as managerial entrepreneurs [22], entrepreneurship in uncertain business environments is seen as requiring creative, even playful, entrepreneurs [23, 24].

Knowledge of facts is not in the core of entrepreneurship; rather entrepreneurship is a way of thinking and acting [25]. Consequently, EE providing knowledge about entrepreneurship does not significantly promote an entrepreneurial mindset, and new approaches are required [26]. According to Engeström [27], uncertain environments require simultaneous creation and learning of new knowledge. Daring experimentation and reliance on one's own and partners' competences are of vital importance because it is practically impossible to collect the information required for managerial decision-making [7].

Modern EE researchers view entrepreneurship as a valid concept in all human activities, not just in business [25, 28]. Accordingly, entrepreneurship is defined broadly, including enterprising behaviors, even outside the business context. In basic education, teachers typically have a strong educational background and EE is seen as an inseparable part of other education. As a consequence, education dominates $\mathrm{EE}$ and the role of entrepreneurship is marginal [29].

Far too often, EE teachers follow outdated definitions of entrepreneurship. We can partly blame the ambiguous definition of entrepreneurship by the European Communities [30] and the Ministry of Education and Culture of Finland [31]. The Finnish ministry defines entrepreneurship as "the individual's ability to translate ideas into action. It encompasses creativity, innovativeness and risk-taking, as well as an ability to plan and direct action towards the achievement of goals" [31]. Even though this definition acknowledges an individual's creative and innovative role in "transforming ideas into action", this definition assumes that the entrepreneurial process starts with an existing opportunity (according to discovery theory) and focuses on "risk-taking attitude (trait theory), skills to plan and meet preset goals" (managing business functions). The EE teachers seem, in their everyday work, to have problems in combining their understanding of pedagogy and entrepreneurship. As a consequence, they either adopt the discovery theory or follow their own observations of how entrepreneurs run their businesses.

Teachers with strong pedagogical backgrounds rely on learning theories based on creativity and experiential and collaborative pedagogical elements. They aim to make curricula closer to reality by utilizing company visits, business games, creativity training, self-directed learning, problem-based learning, distance learning, behavioral simulations, and lifelong learning for those working in industry [32]. Nevertheless, they base their assumptions of entrepreneurship on opposite assumptions than when considering education. In addition, teachers' strong educational backgrounds result in educational choices overshadowing the entrepreneurial ones [33]. Approximately half of teachers put less emphasis on entrepreneurship than on education [33]. 


\subsection{Comparison of ontological conceptions of entrepreneurship and education}

There has been a shift from realism toward idealism in scientific literature on entrepreneurial processes during the early part of the first decade of this millennium. The same shift occurred significantly earlier in the educational literature [34]. In entrepreneurship, the dominant discovery theory that views opportunities as independently existing has been complemented by scholars who see opportunities as created rather than discovered [6, 35, 36]. In education, the shift means that teachers and students interactively create new knowledge together and with the environment rather than that students are given more knowledge, $[12,34,37]$. Table 1 presents our views on the main ontological characteristics of entrepreneurship and education.

\begin{tabular}{lll}
\hline Ontology & Conception of entrepreneurship/opportunity & Conception of education/learning \\
\hline \multirow{2}{*}{ Realism } & Reality exists independently of perceptions of & Reality exists independently of perceptions of it; \\
& it; objectivist ontology/epistemology; & $\begin{array}{l}\text { objectivist ontology/epistemology; } \\
\text { (Dehaviorism: [12, 37]) }\end{array}$ \\
\hline \multirow{3}{*}{ Idealism } & Reality is creations of human actions; & Reality is construction of human behavior; \\
& subjectivist ontology/epistemology; & $\begin{array}{l}\text { subjectivist ontology/epistemology; } \\
\text { (Creation theory: [6]) }\end{array}$ \\
\hline
\end{tabular}

Table 1. Comparison of EE teachers' ontological/epistemological conception of opportunity and education

According to realism, reality exists independently of the observer's perceptions of it. The upper part of Table 1 presents (following realism) entrepreneurship according to discovery theory and education according to behaviorism. Discovery theory and behaviorism have the same ontological starting point, realism, and can therefore be seen to ontologically match with each other. Following idealism, the lower half of Table 1 presents entrepreneurship according to creation theory and education according to social constructionism. According to idealism, reality is created by the observer. We conclude that creation theory and social constructionism match ontologically.

\subsection{Critical realism - A potential way forward}

Realism and idealism can be considered, from the ontological perspective, as two extremities. Critical realism [38] can be located between these two extremes, and is therefore a potential way to ease EE teachers' ontological headache. Critical realism recognizes a reality that is common to everybody, but simultaneously (in line with idealism) views this reality as always being observed and interpreted through human brains. The entrepreneurship concept of creation theory can be described using critical realism so that the objective reality provides material for entrepreneurs to create opportunities or new businesses.

The ontological bases of both discovery theory and behaviorism originate from the realist point of view. This means that, because reality exists independently of the observer [39], EE teachers, their students, and all human beings experience it in the same way [40]. As a result, EE teachers 
need to focus on the content of certain means, which they know are the most feasible for their EE courses. From the learning/teaching point of view, EE teachers need to select appropriate exercises through which students learn what is important for discovering existing opportunities and for developing them successfully through actions in the context of business or elsewhere.

In contrast to the realist viewpoint of behaviorism and opportunity discovery, idealism-based creation theory and social constructionism explicitly shows that, rather than discovering the true nature of reality, people construct multiple realities based on their subjective experiences $[41,42]$. Consequently, EE teachers need to focus on activities that promote students' abilities to construct (or create) their individual reality as well as opportunities they view as feasible for that reality. Then, students will be able to carry on in transforming the created opportunities into real-life activities.

However, if EE teachers do not choose their teaching contents and methods from the matched pairs of discovery-behaviorism and creation-social constructionism (Table 1), they may, we believe, face difficulties in their teaching (e.g., how to cope with a situation in which their teaching is based on both social constructionism and discovery theory). Whereas the former rejects the notion of one true reality to be discovered by human beings, the latter is built on the very same assumption. According to this, EE teachers will be focusing on searching existing opportunities rather than on how to create them individually. This is because there is nothing to be created in the existing reality. Furthermore, if EE teachers' conceptions of teaching and entrepreneurship in the context of EE are based on behaviorism and creation theory, trying to create something not yet existing is unnecessary or impossible if the reality is knowable and the same for all human beings (see: bricoleur in [43]). If students creatively choose their learning methods, a behavioristic EE teacher may begin to think that students are off task and need to get back to real stuff as soon as possible because, in behaviorism, "learners are told about the world and are expected to replicate its contents" [44].

The upper part of Table 1 presents the realism-based views of entrepreneurship and education, whereas the lower part follows idealism. In our story above, we have hinted that, by systematically selecting either the upper or lower part of the table for both entrepreneurship and education, one can avoid the ontological mismatch. However, real situations in the EE context may be very different. For example, EE teachers may wish to utilize teaching methods following social constructionism, even though they simultaneously take discovery theory for granted. In a different case, the deviation from the symmetrical upper or lower part of the table may mean a teacher wishes to behavioristically teach entrepreneurship according to creation theory. Is it possible to avoid the headache of ontological mismatch even if one follows Table 1 diagonally, as described in these two examples? We believe that critical realism enables the conception of reality based on realism and simultaneously accepts the construction of reality according to idealism. Thus, the dichotomy of the table may be potentially eased if one approaches the phenomenon of EE via critical realism. Table 2 explains the nature of critical realism. 


\begin{tabular}{|c|c|c|}
\hline Ontology & Conception of entrepreneurship/opportunity & Conception of education/learning \\
\hline Realism & $\begin{array}{l}\text { Reality exists independently of perceptions of it; } \\
\text { objectivist ontology/epistemology; } \\
\text { (Discovery theory: [6]) }\end{array}$ & $\begin{array}{l}\text { Reality exists independently of perceptions of it; } \\
\text { objectivist ontology/epistemology; } \\
\text { (Behaviorism: }[12,37] \text { ) }\end{array}$ \\
\hline $\begin{array}{l}\text { Critical } \\
\text { realism }\end{array}$ & \multicolumn{2}{|c|}{$\begin{array}{c}\text { Reality exists as source for opportunity creation process; Reality is creative outcome of human } \\
\text { actions; }\end{array}$} \\
\hline Idealism & $\begin{array}{l}\text { Reality is creation of human actions; subjectivist } \\
\text { ontology/epistemology; } \\
\text { (Creation theory: [6]) }\end{array}$ & $\begin{array}{l}\text { Reality is construction of human behavior; } \\
\text { subjectivist ontology/epistemology; } \\
\text { (Social constructionism: }[13,14] \text { ) }\end{array}$ \\
\hline
\end{tabular}

Table 2. Critical realist perspective on EE teachers' ontological conception of entrepreneurship and education

When entrepreneurial process scholars talk about opportunities for future business development in the context of both startups and established firms, they refer to a wide range of actions (see: [46]). If we look at opportunity more thoroughly from a process perspective, opportunity becomes obvious at the same time as we see it, but not before [47]. Then there remain unanswered questions: What do we actually see? Do we see the opportunity as an explicit entity, or as a process? What is the nature of the opportunity, then? If we understand opportunity as an outcome rather than a starting point of the entrepreneurial process, how does this understanding affect this process?

Critical realists claim that people do not only overcome the dichotomy between discoverycreation and behaviorism-social constructionism by defining social reality as existing (the realist ontological positioning). They are also in an active position in dealing with social reality by possessing the power to either reproduce or transform preceding structures [38]. To think about the nature of opportunity more thoroughly, we see that critical realists claim that opportunity exists only in human imagination. That is, it exists as artifact (i.e., documented ideas for future business ventures, business models, or business plans) and manifests itself as imagined opportunities [49].

We believe that critical realism may overcome the dichotomy between realism and idealism by conflating them. As a consequence, human beings are in the position of entrepreneurs and are able to reproduce existing knowledge as artifacts (as in realism), or transform, construct, or create new knowledge through their own imaginations and creativity (as in idealism).

\section{Findings}

\subsection{Ontological conceptions of EE teachers at universities}

In universities, entrepreneurship education teachers tend to either adopt the discovery theory or follow their own instincts originating from their everyday observations of how entrepreneurs seem to manage their businesses. Figure 2 shows EE teachers' typical ontological conceptions at the university level. Discovery and trait theories as well as business functions 
dominate their understanding and, consequently, these traditional theories guide how EE teachers at universities run their EE courses. As a result, EE teachers typically concentrate on how to run a business rather than how to create new business opportunities or how to create a new business.

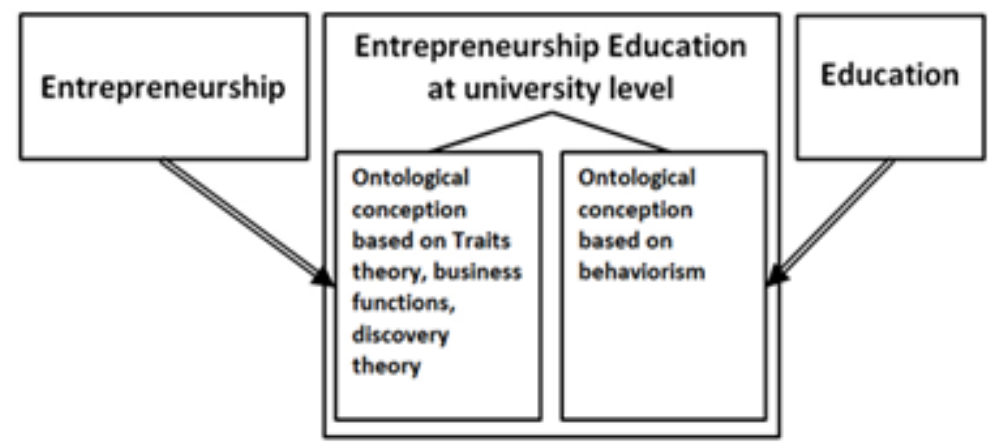

Figure 2. Ontological conceptions of EE teachers at universities

It is noteworthy that there is no ontological mismatch as such between these conceptions of entrepreneurship and education, despite applying the traditional behaviorist perspective on teaching and the traditional conception of entrepreneurship. However, these two outdated conceptions are not optimal because none of them acknowledge the student's active and creative role. From the entrepreneurship viewpoint, this type of understanding means that the students are expected to discover existing opportunities, then use their gained business skills in developing successful businesses. From the educational perspective, students are viewed as passive and are expected to adopt the information their teachers have selected for them.

\subsection{Ontological conceptions of EE teachers in schools at the basic education level}

At the basic education level, EE teachers typically view entrepreneurship as business-related functions and entrepreneurs as opportunity discoverers as well as persons with certain characteristics or traits. Thus, EE teachers at schools share the traditional conceptions of entrepreneurship with university teachers. However, unlike university-teachers who base their teaching on behaviorism, school teachers tend to follow the social constructionist perspective in their teaching, with only some of the older teachers being exceptions. Therefore, there is a mismatch between their conceptions of entrepreneurship and education. In practice, this means that school teachers acknowledge students' active roles in learning and their own roles as facilitators and co-learners. Nevertheless, their conception of entrepreneurship is based on traditional discovery theory, which makes it difficult for them to use their advanced educational backgrounds. Figure 3 shows EE teachers' typical ontological conceptions at the basic education level. 


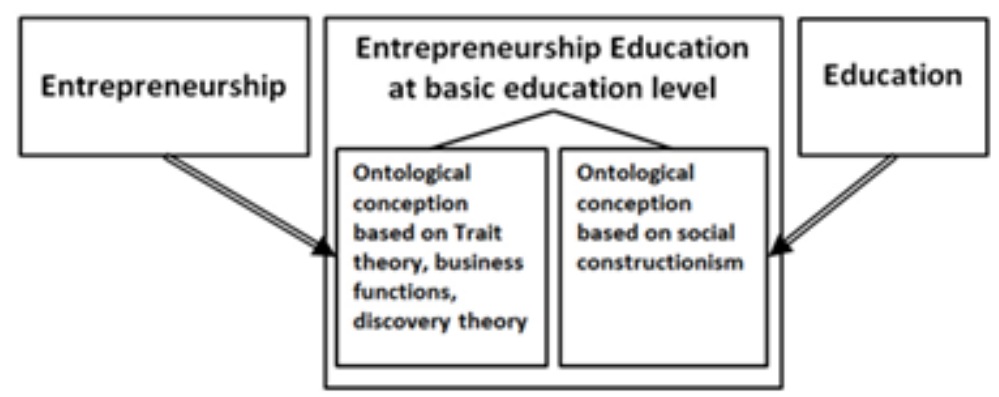

Figure 3. Ontological conceptions of EE teachers in schools at the basic education level

Both the European Commission and the Finnish National Board of Education consider promotion of entrepreneurial behavior as a general goal for European schools. As such, this goal is in line with social constructionism. Nevertheless, a concept that includes the term entrepreneur but is outside of business context may cause further confusion about the meaning of entrepreneurship, as teachers typically understand entrepreneurship in a business context according to discovery theory, which is not in line with social constructionism.

\subsection{Our proposal to ease EE teachers' ontological mismatch-a critical realist perspective}

\subsubsection{Theoretical basis for our proposal}

We believe that EE teachers may ease the ontological mismatch they face in their teaching by selecting the conceptions of entrepreneurship as opportunity creation and education as social constructionism. However, by choosing the critical realist perspective, EE teachers can use some aspects from both idealism and realism. That is, one can accept some things as existing and simultaneously accept other things as human creations. In the context of EE, this means that EE teachers may base their everyday teachings on something that they take as given, and on something they create themselves, together with their students.

The entrepreneurial opportunity creation process typically starts after people feel they have found something interesting through observing their everyday realities (according to realism). After this finding, the opportunity process continues iteratively through creation and recreation, potentially leading to a business venture (reality is created by human actions, according to idealism). The same process often takes place outside the business context as well. This process includes elements from both realism and idealism potentially causing ontological headaches for EE teachers. Critical realism may ease these headaches.

Critical realist perspective allows us to see that entrepreneurs (i.e., key actors of the opportunity creation process) are deeply embedded in their social and natural realities (environments). This means that they may interact with other people and that they may find interesting and utilizable sources for their opportunity-creating processes. As Figure 4 shows, the construct of opportunity includes three sub-processes (future business ideating, business modeling, and 
business planning). In each sub-process, the entrepreneur utilizes creative problem-solving (CPS) [50] for creating an outcome that becomes an input for the other two sub-processes in an iterative manner. Each sub-process has an idealist ontological foundation; however, the output of this sub-process is viewed as a realism-based input for other sub-processes.

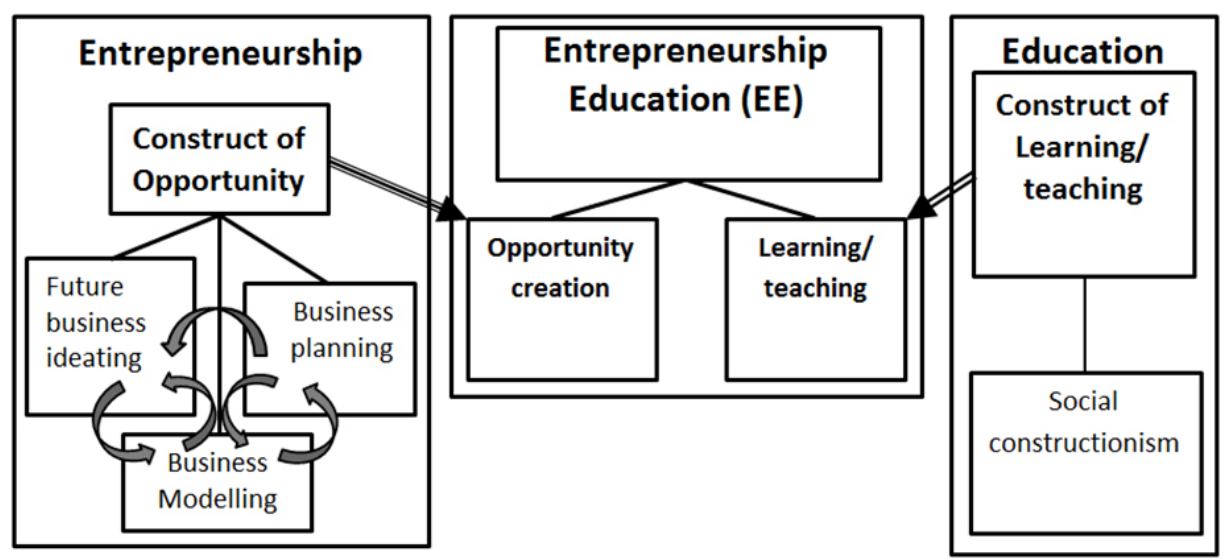

Figure 4. Entrepreneurship Education (EE) as integration of entrepreneurship and education

By defining entrepreneurship as an entrepreneurial process focusing on opportunity creation and education focusing on social constructionism opens up new avenues for EE teachers and students. The EE teachers and students will be capable for creating opportunities rather than just finding them. Furthermore, EE teachers may apply this kind of process both in business context and outside of it, even in the educational context. In addition, this process is applicable at every educational level because it is up to the EE teacher and participating students to decide into which direction they order each sub-process.

\subsubsection{Practical application of our proposal}

Table 3 illustrates our proposal, which is based on the idea of seeing EE as an integration of entrepreneurship and education. We emphasize the importance of both these elements; entrepreneurship gives the context and education offers the method for EE teachers to facilitate students' learning processes. Both of these EE elements can be based on critical realism. Further, we believe that seeing entrepreneurship through a process perspective will help EE teachers to overcome the confusion of comprehending how to exploit entrepreneurship in business, education, or any other non-business context. We also believe that this approach is valid at all levels of education and also outside business and economics studies. Our proposal is applicable for any activity students want to create for the benefit of themselves, their friends, their acquaintances, their customers, or their end-users. We use the term activity in any nonbusiness context in a manner similar to the use of the term business to describe business opportunity, business modeling, and business planning. 
As shown in Figure 4, we base our suggestion on the construct of opportunity consisting of three sub-processes: ideating an initial idea for future business, business modeling, and business planning. Even though these three sub-processes are typically seen as pure businessfocused processes, we now apply these into the educational context and label them as follows: ideating an initial idea for a new activity, activity modeling, and activity planning. See Table 3 for details.

Our processual approach to EE starts after people have imagined and reached new thoughts during their everyday lives. Only some of these thoughts are worth further elaborating. If a thought is considered desirable enough, then it is time to start a business/activity opportunity process to creatively develop it into a full-blown business/action opportunity that is ready for implementation (or exploitation). As shown in Table 3, people will go through every subprocess by utilizing the CPS method (i.e., divergent thinking-clustering-convergent thinking in [50]). This method helps people in the position of an entrepreneur or student (or even an EE teacher) to generate a lot of possible answers to interesting questions, to create expected and unexpected combinations between them, and to then select the most desirable combination to be used as an input for further CPS actions in the next sub-process. If all combinations in clustering are felt to be unsatisfactory, people may start the sub-process again. Alternatively, they may go back a previous sub-process to create a different output.

In the position of entrepreneur or student, or even in the position of EE teacher, people start asking questions when ideating, such as: Who is the customer/end-user/beneficiary? How do I get in contact with them? What is the value proposition? What is our own commitment? (See: 4 Cs in [51]). After creating a great amount of possible and impossible answers based on divergent thinking, people try to find new, unexpected, innovative combinations between ideas (clustering) to proceed with the most promising one.

We believe that by using nine elements (value proposition, channels, customer relationships, revenue streams, key resources, key activities, key partners, and cost structure) originally developed for business (Business Model Canvas (BMC) in [51, 52]), it is possible to define all the elements of the business/activity model to understand that any change in one element will actually affect the entirety. Familiarizing with BMC helps in modeling elements of business/ activity element by element, and to understand that any change in one element will actually affect the entirety. Any change may open up new avenues during the modeling process. It is useful to generate as many different versions as possible to see what may even be surprising ways to build future business/activity. The outcome of modeling represents a conceptual description of a desired model of future business or other activity and the input for the following sub-process.

According to our interpretation of EE literature, EE teachers have treated business planning as the key content of EE (at least at the secondary and tertiary levels of the education system). At the same time, some scholars in the field of entrepreneurship have questioned its importance (e.g., because of the strong focus on convergent thinking, that is, how to make rational plans for implementing the desired B/A model into real-life context [54, 55]). However, we see that from the CPS point of view, one may use creativity (defined as novel and feasible outcome) in business/activity modeling. 
From everyday idea to ideating future business/action through Creative Problem Solving (CPS: divergent thinking - clustering - convergent thinking) - focus on desirability

Ideating an initial idea for future business

Including:

Our key customer is ...

Our value proposition ...

We contact our customer with ...

Our commitment to the idea ...

\section{Ideating an initial idea for future activities}

Including:

Our activity benefits ...

The value we try to bring to them is ...

We contact our people with ...

We will go as far as...

OUTCOME/INPUT:

This idea is the most promising!

This is with what I/we want to proceed.

This is how I/we like to do.

From initial idea for future action to creating Business/Activity Model through Creative Problem Solving

(CPS: divergent thinking - clustering - convergent thinking) - focus on the big picture

\section{Business Modeling (BM)}

The most desirable and selected BM includes descriptions of:

means that would generate the proposed value customer segmentation

abilities and competences to execute BM

value gathering for business venture entrepreneur's satisfaction

\section{Activity Modeling (AM)}

The most desirable and selected AM includes descriptions of: means that would generate the proposed value to whom activities are meant for objects abilities and competences to execute AM what it will give for us

OUTCOME/INPUT:

Conceptual description of desired activity

From Business/Action Model to creating Business Plan through Creative Problem Solving

(CPS: divergent thinking - clustering - convergent thinking) - focus on implementation

\section{Business Planning (BP)}

Creating the implementation plan for the most desirable $\mathrm{BM}$

\section{Activity Planning (AP)}

Creating the implementation plan for the most desirable

$$
\mathrm{AM}
$$

\section{OUTCOME:}

Plan for implementing the BM/AM

Table 3. Business/action opportunity creation in the entrepreneurship education context

\section{Conclusion}

This chapter discussed the entrepreneurship education teachers' ontological conceptions of entrepreneurship and education and studied potential mismatches in these conceptions. We 
started with analyzing literature on entrepreneurship and education. The analyzed literature included scientific journal articles, project reports, and official documents at the European and national levels discussing EE. We concluded from this literature review that there is an ontological mismatch between entrepreneurship and education because the development of education is ahead of entrepreneurship in the paradigm shift from realism to idealism. This mismatch is visible in scientific thinking and also appears, according to our theoretical analysis and practical observations, as an ontological headache in practicing EE teachers' conceptions of entrepreneurship and education.

According to our results, EE teachers in basic education at the primary and secondary levels have a strong pedagogical education and tend to base their pedagogical thinking on social constructionism. At the same time, however, they tend to follow a traditional view of entrepreneurship that is the opposite of their pedagogical thinking. Conversely, university teachers, with backgrounds in, for example, business school or technology, all too often tend to base their pedagogical thinking on behavioristic pedagogy. At the same time, they tend to emphasize managerial competencies, business functions, etc. in entrepreneurship education. These empirical observations confirm our conclusions in the conceptual reasoning that there might be an ontological mismatch between entrepreneurship and education.

To ease the EE ontological headache, we have used the critical realist perspective in entrepreneurship and education as well as in their integration (i.e., in EE). The critical realist perspective bridges, on the one hand, realism-based discovery theory and idealism-based creation theory, and on the other, realism-based behaviorism and idealism-based social constructionism. Combining the critical realist perspective with the processual view on entrepreneurship enables acceptance that reality exists as a source for the opportunity creation process, and simultaneously, that reality is a creative outcome of human actions.

Based on critical realism, we suggest a practical model for EE teachers to use as content for their EE. We believe EE students will be able to utilize the model in both a business and nonbusiness context when they wish to create new activities. In the business context, this may mean better abilities to create their own business startups or to create new business activities in established firms. In the non-business context, students may use the model to create activities in different types of organizations, including their schools.

In this chapter, our aim was to address the calls for theoretical and conceptual studies in entrepreneurship education focusing on ontological issues. Entrepreneurship education can be seen as an integration of entrepreneurship and education, and we argue that the ontologies of both of these EE components influence EE. Therefore, we have first juxtaposed the theoretical paradigm shifts in entrepreneurship and education from the ontological viewpoint. We have taken a first cut at building a practical model to ease the ontological headaches of EE actors with respect to the concept of entrepreneurship and the educational methods for teaching it. 


\section{Author details}

Kaarlo Paloniemi ${ }^{1^{*}}$ and Pekka Belt ${ }^{2}$

*Address all correspondence to: kaarlo.paloniemi@oulu.fi

1 Oulu Business School, University of Oulu, Oulu, Finland

2 University of Oulu, Oulu, Finland

\section{References}

[1] Fiet JO. The theoretical side of teaching entrepreneurship. Journal of Business Venturing 2000; 16(1) 1-24.

[2] Seikkula-Leino J. Advancing entrepreneurship education in the Finnish basic education-the prospect of developing local curricula. The dynamics between entrepreneurship, environment and education 2008; 168-90.

[3] Solomon G. An examination of entrepreneurship education in the United States. Journal of Small Business and Enterprise Development 2007; 14(2) 168-182.

[4] Ruskovaara E, Pihkala T. Teachers implementing entrepreneurship education: classroom practices. Education+Training 2013; 55(2) 204-216.

[5] Fayolle A. Personal views on the future of entrepreneurship education. Entrepreneurship \& Regional Development 2013; 25(7-8) 692-701.

[6] Alvarez SA, Barney JB. Discovery and creation: Alternative theories of entrepreneurial action. Strategic entrepreneurship journal 2007; 1(1-2) 11-26.

[7] Sarasvathy SD. Causation and effectuation: Toward a theoretical shift from economic inevitability to entrepreneurial contingency. The Academy of Management Review $2001 ; 26243-263$.

[8] Skinner BF. Origins of a Behaviorist. Psychology Today 1983; 22-33.

[9] Berger PL, Luckmann T. The social construction of reality: A treatise in the sociology of knowledge No. 10. Penguin UK; 1991.

[10] Gergen KJ. The social constructionist movement in modern psychology. American Psychologist 1985; 40(3) 266-275.

[11] Cooper PA. Paradigm Shifts in Designed Instruction: From Behaviorism to Cognitivism to Constructivism. Educational technology 1993; 33(5) 12-19. 
[12] Richardson V. From Behaviorism to Constructivism in Teacher Education. Teacher Education and Special Education 1996;19(3) 263-271.

[13] Palincsar, A. S. (1998). Social constructivist perspectives on teaching and learning. Annual Review of Psychology, 49, 345-375.

[14] Vygotsky, L. S. (1978). Mind in society. Cambridge, MA: Harvard University Press.

[15] Boghossian P. Behaviorism, Constructivism, and Socratic Pedagogy. Educational Philosophy and Theory 2006; 38(6) 713-722.

[16] Hayward LM. Becoming a self-reflective teacher: a meaningful research process. Journal of Physical Therapy Education 2000; 14(1) 21-30.

[17] Jones C, Penaluna A. Moving beyond the business plan in enterprise education. Education+Training 2013; 55(8/9) 804-814.

[18] Shane S, Venkataraman S. The promise of entrepreneurship as a field of research. The Academy of management review 2000; (2) 217-226.

[19] Dew D, Read S, Sarasvathy SD, Wiltbank R. Effectual versus predictive logics in entrepreneurial decision-making: Differences between expert and novices. Journal of Business Venturing 2008; 24 287-309.

[20] Read S, Sarasvathy SD. Knowing What to Do and Doing What You Know: Effectuation as a Form of Entrepreneurial Expertise. The Journal of Private Equity 2005; 945 61.

[21] Sanz-Velasco SA. Opportunity development as a learning process for entrepreneurs. International Journal of Entrepreneurial Behaviour \& Research 2006; 12 251- 271.

[22] Hjorth D. Rewriting Entrepreneurship-for a New Perspective on Organisational Creativity. PhD thesis. Lund University; 2003.

[23] Hjorth D. Creating space for play/invention - concepts of space and organizational entrepreneurship. Entrepreneurship and Regional Development 2004; 16 413-432.

[24] Steyaert C, Katz J. Reclaiming the space of entrepreneurship in society: geographical, discursive and social dimensions. Entrepreneurship and Regional Development 2004; 16 179-196.

[25] Gibb AA. The Enterprise Culture and Education: Understanding Enterprise Education and its Links with Small Business, Entrepreneurship and Wider Educational Goals. International Small Business Journal 1993; 3 11-34.

[26] Bennett M. Business lecturers' perception of the nature of entrepreneurship. International Journal of Entrepreneurial Behaviour \& Research 2006; 12 165-188.

[27] Engeström Y. Expansive learning at work: toward an activity theoretical reconceptualization. Journal of Education and Work 2001; 14 133-156. 
[28] Kirby DA. Entrepreneurship education: can business schools meet the challenge? Education+Training 2004; 46 510-519.

[29] Fayolle A, Gailly B, Lassas-Clerc N. Assessing the impact of entrepreneurship education programmes: a new methodology. Journal of European industrial training 2006; 30(9) 701-720.

[30] Commission of the European Communities. Brussels, 10.11.2005. COM 548 final. 2005/0221(COD). Proposal for a RECOMMENDATION OF THE EUROPEAN PARLIAMENT AND OF THE COUNCIL on key competences for lifelong learning; 2005.

[31] Ministry of Education and Culture of Finland Guidelines for entrepreneurship education. Publications of the Ministry of Education 2009:9.

[32] Wilson K. Entrepreneurship education in Europe. In: Jonathan P. (ed.) Local Economic and Employment Development (LEED) Entrepreneurship and Higher Education (No. 18). OECD Publishing; 2008; 119-138.

[33] Gustafsson-Pesonen A, Kiuru P. Ideoita ja oivalluksia yrittäjyyskasvatukseen YKOONTI. Aalto-yliopiston julkaisusarja KAUPPA+TALOUS 2012; 4/2012.

[34] Knoester M. Who will benefit from 'the sociocultural turn' in education? Pedagogy, Culture \& Society 2011; 19(2) 311-318.

[35] Ardichvili A, Cardozo R, Ray S. A theory of entrepreneurial opportunity identification and development. Journal of Business Venturing 2003; 18 105-123.

[36] Sarasvathy SD, Dew N, Velamuri SR, Venkataraman S. Three views of entrepreneurial opportunity. In: Audretsch DB, Acs ZJ. (eds.) Handbook of entrepreneurship research. New York: Springer; 2010; 77-96.

[37] Cooper PA. (1993). Paradigm Shifts in Designed Instruction: From Behaviorism to Cognitivism to Constructivism. Educational technology 1993; 33(5) 12-19.

[38] Archer M. Realism and morphogenesis. In Archer M, Bhaskar R, Collier A, Lawson T, Norrie A. (eds.) Critical Realism: Essential Readings. Routledge; 1998; 356-382.

[39] Casti JL. Paradigms lost: Tackling the unanswered mysteries of modern science. New York: Avon Books; 1989; 15-48.

[40] Osborne JF. Beyond constructivism. Science Education 1996; 80(1) 53-82.

[41] Driscoll MP. Psychology of Learning for Instruction. Boston, MA: Allyn \& Bacon; 1994.

[42] Nola R. Relativism and Realism in Science. Dordrecht, The Netherlands: Kluwer; 1988.

[43] Garud R, Karnøe P. (2003). Bricolage versus breakthrough: distributed and embedded agency in technology entrepreneurship. Research policy 2003; 32(2) 277-300. 
[44] Jonassen D. Evaluating Constructivist Learning. Educational Technology 1991; 36(9) 28-33.

[45] Fleetwood S. Ontology in Organization and Management Studies: A Critical Realist Perspective. Organization 2005; 12(2) 197-222.

[46] Scott D. Critical realism and empirical research methods in education. Journal of Philosophy of Education 2005; 39(4) 633-646.

[47] Corbett AC, Katz JA., editors. Entrepreneurial Action. Emerald Group Publishing; 2012.

[48] Dimov D. Grappling with the unbearable elusiveness of entrepreneurial opportunities. Entrepreneurship Theory and Practice 2011; 35(1) 57-81.

[49] Klein PG. Opportunity, discovery, entrepreneurial action and economic organization. Strategic Entrepreneurship Journal 2008; 2 175-190.

[50] Tassoul M, Buijs J. Clustering: An Essential Step from Diverging to Converging. Creativity and Innovation Management Journal 2007; 16(1) 16-26.

[51] Gartner WB, Bellamy MG. Enterprise. 1st ed. Cengage Learning; 2010.

[52] Osterwalder A. The business model ontology: A proposition in a design science approach. PhD thesis. Institut d'Informatique et Organisation. Lausanne, Switzerland, University of Lausanne, Ecole des Hautes Etudes Commerciales HEC; 2004.

[53] Osterwalder A, Pigneur Y, Tucci CL. Clarifying Business Models: Origins, Present, and Future of the Concept. Communications of the Association for Information Systems 2005;16 1-25.

[54] Honig B. Entrepreneurship education: Toward a model of contingency-based business planning. Academy of Management Learning \& Education 2004; 3(3) 258-273.

[55] Delmar F, Shane S. Does business planning facilitate the development of new ventures? Strategic Management Journal 2003; 24(12) 1165-1185. 